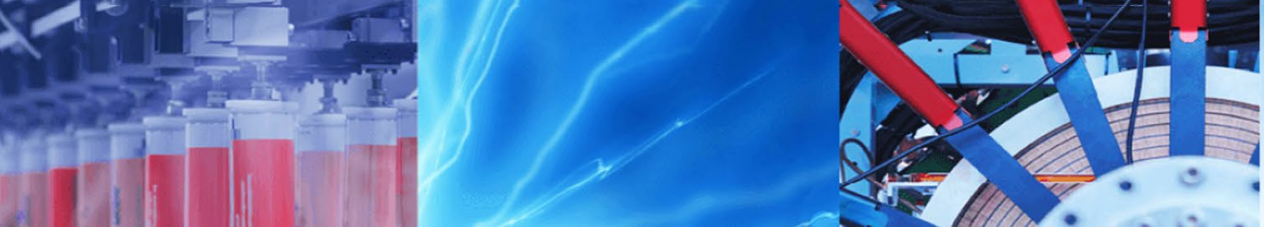

Research Article

\title{
Textural features and transportation mode of Nile Delta coastal lagoon surficial sediments (Lake Burullus, Ramsar Site)
}

\author{
Hassan I. Farhat ${ }^{1}$ (D) \\ (c) Springer Nature Switzerland AG 2019
}

\begin{abstract}
The present study aims to give a comprehensive account of the sedimentological characteristics and sedimentary processes action on Nile Delta coastal lagoon. The study carried out on 15 surficial sediments samples collected from Lake Burullus. Through a detailed sedimentary texture study and using applications (CM diagram, bivariate diagrams and multivariant linear discriminant functions) sediment source, transportation and accumulation of Lake Burullus are suggested. Results revealed that the increased coarse fractions northward near inlets were due to wave actions which indicate the high-energy transporting environments. Moreover, Areas of drains effluents, fine fractions are trapped and deposited directly after the entering of the lagoon, then it well-ordered by hydraulic sorting. Mean grain size is mostly controlled by sediments sources. Sediment sorting is mainly poor indicating turbulent conditions. Skewness results indicate that lagoon is classified as environments undergoing depositional trends spatially southward. The CM divulges that the deposition takes place by homogenous suspension and rolling. With strong freshwater processes signatures, turbidite deposition, and siltation are more than truncation in the main transportation mode.
\end{abstract}

Keywords Lake Burullus · Coastal lagoon · Sedimentological characteristics · Sediments transportation · Nile Delta

\section{Introduction}

Lagoons are coastal bodies of water that have limited connection to the open sea; at least one or more of inlets. Lagoons usually located parallel to the shore. Along many coastlines, a lagoon is separated from open sea by a barrier. Barriers are composed of sand and/or gravel material, it are largely built up as results of wave action. Barriers range in size from less than $100 \mathrm{~m}$ wide to several kilometers. Lagoons are characteristically very shallow, reaching only a few metres in depth [48]. A lagoonal sediments is typically mudstone, frequently organic-rich, with thin, wave-rippled sand lamina [3]. In present study, we work on the Burullus Lake as a good example of coastal lagoons, Lake Burullus is one of "Egyptian" Mediterranean coasts lagoons, which represents Ramsar site and has been declared as a natural protectorate in 1998. It is a perfect coastal wetland depositional basin that received marine and freshwater from two main sources, Mediterranean Sea water via El-Borg outlet (a natural water pass) and freshwater from several other drains [54]. Coastal lagoons have great geological and ecological importance due to their special hydrological features, it is acting as transitional sites between terrestrial and marine environments. In addition to food supply, flora and fauna diversity, and biomass productivity.

Grain-size distribution, light minerals petrography, surface morphology, and rounding of quartz grains and heavy-mineral assemblage's compositions are different techniques that has been widely used for defining sediments sources, depositional environment, and transportation mode. Each of them indicates its specific information, which complements the other data $[23,26,31-33,59,61]$.

$\triangle$ Hassan I. Farhat, hassan.farhat@suezuniv.edu.eg|' Geology Department, Faculty of Science, Suez University, Suez Governate, El Salam City 43518, Egypt.

SN Applied Sciences (2019) 1:1013 | https://doi.org/10.1007/s42452-019-1053-8 
Sediments show spatial variations in their textural parameters within the same environment, depending on its transporting processes. Three mechanisms control the grain size trends: abrasion of sedimentary particles, hydraulic sorting, and different sources mixed materials $[49,57]$. Accordingly, the study of the relationship between grain-size distributions and sediment mode of transportation explain sediment transportion agents and their depositional environment [27-29, 36, 38, 42, 43, 45]. Studies of grain size distribution indicate basic relation between properties of sediments and their depositional environment $[11,16,17,33,38,58,60]$. Furthermore, sediment aggregations, transport processes, the sedimentation conditions, transport-related features, deposition, gravitational circulation, and tidal trapping are different factors controlling grain size distribution even if it acted separately or combined $[11,33,38,60]$.

Moreover, the physical, chemical, and biological parameters are considered the main regulators governing sedimentation in lakes and rivers. The physical processes are predominating in rivers, particularly those associated with the unidirectional flow of water. While the chemical and biological processes generally have equal or greater effects than physical in lakes. Furthermore, the physical processes acting on lakes are varied than those acting on rivers. Not only unidirectional flow from fluvial input, but also the action of wind and waves and gravitational processes have great effects on sedimentation processes [50]. Coastal lagoons are usually located at termini of irrigations systems, making them a depositional pool with a unique depositional system because it is characterized by bi-directional horizontal flows and strong changes in residence time. The continuous inflow of fresh and marine-water cause large temporal and spatial variations in sediments characteristics and distribution $[3,4,10,35]$.

One of most important indicators of depositional environments is sediment texture. It used as a proxy for potential storm transport and it may used with other parameters to differentiate whether sediments come from the sea or from the land. Also, in lagoons it may used to provide a relevant geomorphic setting to track palaeostorm activity [21].

The present study aims to deeply understand and interpret the textural features as indicators for both of sedimentological characteristics and sedimentary processes acting on Lake Burullus; as a perfect site of the coastal lagoon; in terms of special variation in grain size distribution, mode of transportation, and origin of the depositional environment.

\section{Materials and methods}

\subsection{Study area}

Burullus Lagoon is the second largest Egyptian Mediterranean coastal lagoon $(53 \mathrm{~km}$ length, $13 \mathrm{~km}$ width, and 0.5 to $2.5 \mathrm{~m}$ depth). It is located in the center of the Nile delta. It lied between the two main Nile branches Rosetta to the west and Damietta to the east. It has an elongated elliptical shape between longitudes $30^{\circ} 31^{\prime}$ and $31^{\circ} 05^{\prime} \mathrm{E}$ and latitudes $31^{\circ} 25^{\prime}$ and $31^{\circ} 35^{\prime} \mathrm{N}$ (Fig. 1). The Lagoon is connected to the Mediterranean Sea by El-Burg inlet, which is located at its northeast side and is separated from the sea by coastal strip, consisted mainly from sand sheets and dunes (0.4 to $5.5 \mathrm{~km}$ width) [7]. Burullus Lagoon receives drainage water through eight drains in addition to fresh water from Brimbal Canal (southwestward) [37].

\subsection{Sampling}

During December 2016, fifteen sediment samples were collected from the investigated lagoon to cover all the lagoon area, each location were selected to represent different depositional characteristics of each site e.g. near inlet, near drain effluents, and lagoon main basin (Fig. 1). Samples were collected using Ekman dredge sampler (with volume of $30 \mathrm{~cm}^{3}$ ). Lagoonal bottom sediment samples were packed in air-tight polythene bags, Then subsamples of the sediments were oven dried at $105^{\circ} \mathrm{C}$ to constant weight for analyzing uses.

\subsection{Analysis}

\subsubsection{Grain size analysis}

Half of each sample was put in a beaker then $\mathrm{HCl}(10 \%)$ and anhydrous crystals of $\mathrm{SnCl}$ were added to remove carbonates and salts, and then washed. $\mathrm{H}_{2} \mathrm{O}_{2}(30 \%)$ were added to remove organic matter [14]. Finally, the samples were washed with distilled water and stirred until no flocculation was observed. Sediment was dried in an oven at $105^{\circ} \mathrm{C}$.

After the quartering of the dried sample, the grain size analysis was processed by dry sieving technique. The sieves set were arranged where one phi interval separated each sieve form the other (seven sets arranged from $2 \mathrm{~mm}$ to $0.063 \mathrm{~mm}$ and pan: to collect mud fraction less than $63 \mu$ ) [15]. Each sample contains mud fraction (less than $63 \mu \mathrm{m}$ ) more than $5 \%$ were analyzed using the 
Fig. 1 Sampling locations of sediment samples from Burullus Lake

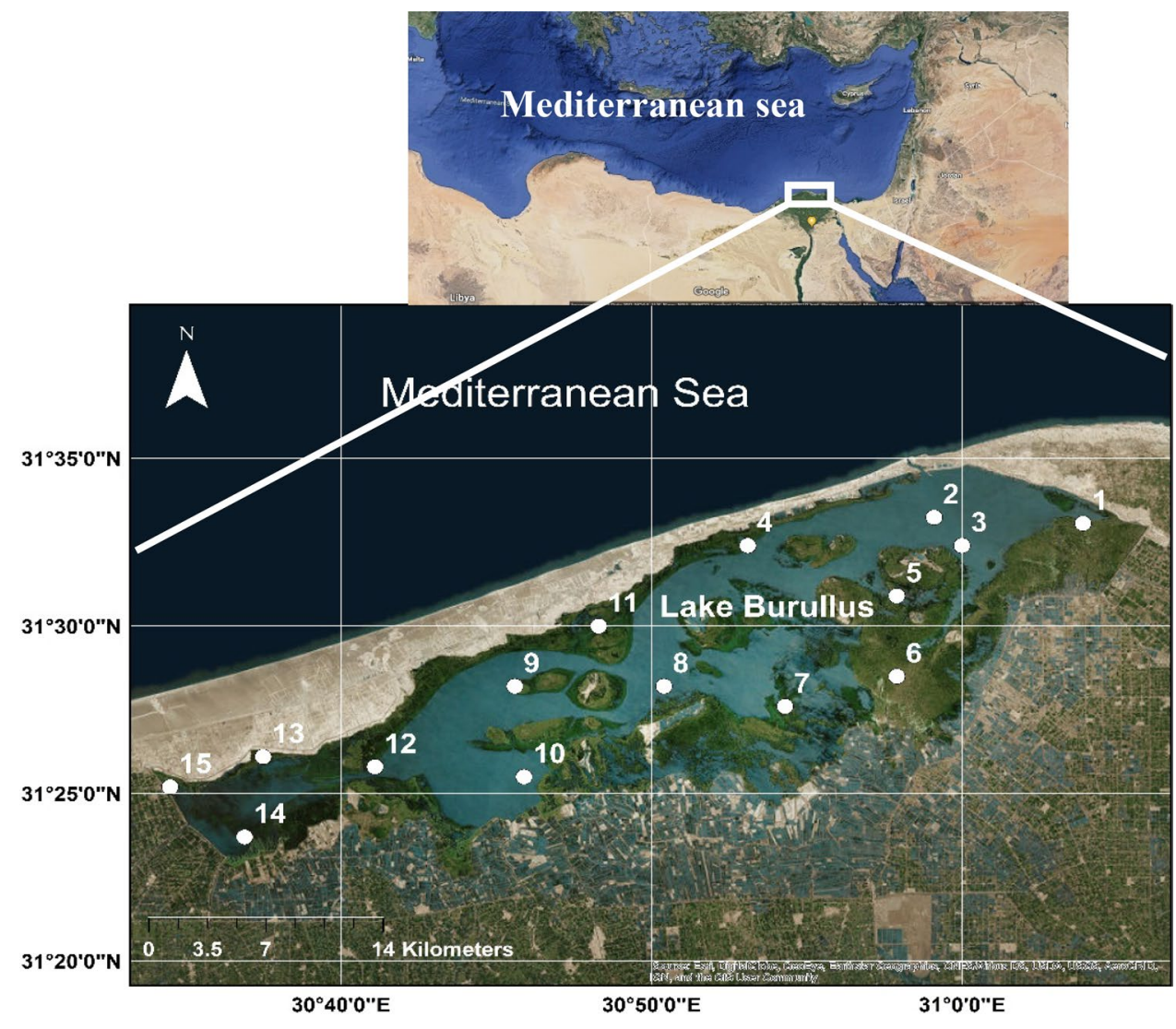

pipette method described by Carver [5] and Folk [15]. The grain size data obtained was represented by using arc GIS $10^{\circledR}$ program to present the interpolation of grain size distribution over all of studied lagoon.

Textural parameters Cumulative curves were plotted on a semi-log probability scale. Textural parameters (mean size $\left(M_{z}\right)$, median $(M d)$ sorting $\left(\sigma_{1}\right)$, skewness $\left(S_{1}\right)$ and kurtosis $\left(\mathrm{K}_{\mathrm{G}}\right)$ ) were calculated according to Folk and Ward [16] and Folk [15].

The data of textural parameters obtained was represented by using arc GIS $10^{\circledR}$ program to present the interpolation of grain size distribution over all of studied lagoon.

\subsubsection{Mode of transportation}

By using results obtained from grain-size, CM diagram (Where the values of " $\mathrm{C}$ " the first percentile are plotted against the " $\mathrm{M}$ " median grain diameter) and truncation lines at inflection points of the cumulative curves have been drawn to identify the mechanics of transportation $[33,39-41,58]$. Two bivariate diagrams were used in the present work following Friedman $[17,18]$ and Moiola and Weiser [30] diagrams in which plotting skewness vs sorting, mean size vs sorting, respectively.
The deposition environment of lagoon sediments has been illustrated according to Sahu [52] by using multigroup, multivariant linear discriminant functions. The following equations are used for calculating $\mathbf{V}_{\mathbf{1}}$ and $\mathbf{V}_{\mathbf{2}}$ functions, adopting the Eigen-vector matrices of Sahu [52]:

$\mathbf{V}_{\mathbf{1}}=0.48048 \mathbf{M}_{\mathbf{Z}}+0.6231\left(\boldsymbol{\sigma}_{\mathbf{I}}\right)^{2}+0.40602 \mathbf{S K}_{\mathbf{I}}+0.44413 \mathbf{K}_{\mathbf{G}}$ $\mathbf{V}_{\mathbf{2}}=0.24523 \mathbf{M}_{\mathbf{Z}}-0.45905\left(\boldsymbol{\sigma}_{\mathbf{I}}\right)^{2}+0.15715 \mathbf{S K}_{\mathbf{I}}+0.83931 \mathbf{K}_{\mathbf{G}}$ where $\mathbf{M}_{\mathbf{Z}} ;\left(\boldsymbol{\sigma}_{\mathbf{I}}\right)^{\mathbf{2}} ; \mathbf{S} \mathbf{K}_{\mathbf{I}}$ and $\mathbf{K}_{\mathbf{G}}$ are mean size, variance, skewness, and kurtosis, respectively.

\section{Results}

\subsection{Grain size analysis}

The results revealed that the sediments of the studied lagoon are a mixture of sand and mud (Generally, muddy sand), even though coarser fractions; gravel fraction; are distributed in rare sites. It is represented as shells and shell fragments. Gravel size reaching to $44.52 \%$ at the north-central area of lagoon (site 11). The sand fractions were the dominant fraction. Sand sizes varied between (12.79-92.12\%) (site 15 (front of Brembal Canal) and site 2 (front of Boughaze area), respectively). Fine sand 
(reached to $61.14 \%$ at site 3; Boughaz area) and very fine sand (reached to $37.24 \%$ at site 4 ; west to Boughaz) were the dominant sand fractions with less amount of other sand fractions (Table 1). The mud fraction (silt and clay) of the surficial sediments of the investigated lagoon is dominated by silt fraction $(<3.15-45.31 \% ; 4-63 \mu \mathrm{m})$ at the north-central area of the lagoon at site 11 (Mastaroh area) and eastward at site 1 (front of East Burullus drain area), respectively. Additionally, various amounts of clay fraction $(0.82-7.44 \% ;<4 \mu \mathrm{m})$ were obtained at site 2 (front of Boughaze area) and south-westward at site 15 (front of Brembal Canal). Silt fractions were represented by coarse and medium and fine silt (reached to 23.29, 16.35 and $48.06 \%$, respectively) with lesser amounts of fine silt fractions (Fig. 2 and Table 1).

Sediment type varies depending on sampling sites. Generally muddy sand was dominant eastward and central areas of Lake Burullus, whereas far west at site 15 (front of Brembal Canal) was sandy mud. In addition, depth controls the sediment type. It directly proportion with both of mud and clay distribution ( $r=0.79$ and 0.76 , respectively) (Fig. 2 and Table 1).

\subsection{Textural parameters}

The main size fluctuates between coarse sand $(0.75 \varnothing)$ northward at site 11 (Mastroh area) and medium silt (5.77Ø) at site 15 (front of Brembal Canal area). Generally, sorting is poorly sorted ( 1 to $2 \varnothing$ ) at all of the lagoon region except at site 2 (Boughaze area) it is medium well sorted $(0.6 \varnothing)$. The skewness is generally very fine skewed eastward, and fine-skewed at the central area of the lagoon, while is coarsely skewed $(-0.28)$ south-westward. Kurtosis varies between very lepto-kurtic (0.51) northward at site 11 (Mastaroh) and very platy-kurtic at westward at site 12 (Abu Amer area) (Fig. 3 and Table 2).

\subsection{Mode of transportation and depositional environmental interpretation}

\subsubsection{Application of the $\mathrm{CM}$ diagram}

By using of CM diagram, results of grain-size distributions of lagoon sediments have been studied with the intention of explaining the mechanism of transportation and deposition. Where the values of " $C$ " the first percentile are plotted against the " $M$ " median grain diameter.

According to Passega [39, 40], Passega and Byramjee [41] and Mycielska-Dowgiałło and Ludwikowska-Kędzia [33] results indicate that mode of transportation of most of the lagoon areas are homogeneous suspension (S-R) (Boughaz area (2), eastward (sites 3, 5, 6), northward (site 4), southward (site 7) and westward (sites 10, 12)). While the mode of transportation of sediments of sites $8,9,11$, 13 and 14 are by rolling. The pelagic suspension is represented only by area facing Bermbal Canal (site 15). Whereas only site 1 is suspension with some rolling (Fig. 4 and Table 3).

\subsubsection{Truncation lines at inflection points of the cumulative curves}

Concerning the modes of sediment transportation, according to Visher [58] and Mycielska-Dowgiałło and Ludwikowska-Kędzia [33] Burullus lagoon sediments showed that truncation between traction and saltation highest value is recorded at site 2 (Boughaz area) with a weight percentage of $96 \%$. A prominent truncation between traction and saltation at a range of 1.00 and 5.00 $\varnothing$ with weight percentage ranged between 2.5 and $98.0 \%$. Truncation between saltation and suspension highest values is recorded at areas faced drains effluents. Truncation between saltation and suspension is ranged between 4.00 and $9.00 \varnothing$ with weight percentage is ranged between 32.0 and $49.5 \%$. In addition, results clear that Truncation between saltation and suspension is dominant by $8 \varnothing$ with weight percentage ranged between 1.2 and $96.0 \%$. Suspension load ranged between 0.8 and $7.5 \%$ (Table 3 ).

\subsubsection{Bivariate plots}

Plotting of the textural parameters results on the bivariate diagram of sorting vs skewness (Fig. $5 \mathrm{a}$ ) according to Friedman [18] and Moiola and Weiser [30] revealed that all the sediment samples fall in the field of freshwater deposits. The other bivariate of mean size vs. sorting according to Friedman [17] (Fig. 5b) supports a freshwater regime for deposition of lagoon sediments.

\subsubsection{Multigroup multivariant discriminant functions V1- V2 plot}

According to Sahu [52], a rigorous statistical method of multigroup multivariant linear discriminant functions was used for estimating the environment of deposition of Lake Burullus surficial sediments. Results obtained by the discriminant functions of $\boldsymbol{V}_{\mathbf{1}}$ and $\boldsymbol{V}_{\mathbf{2}}$ (Table 3 ) were plotted on the multigroup multivariant discriminant diagram (Fig. 6). Only one sample (site 15; area facing Bermbal Canal) fall in the field of the riverine environment, while samples of all other sites represent the turbidite environments deposition. This may be due to the low depth of water column, which records great wind activities effect on sediment and redeposition of fine sediments in relatively deeper areas. 


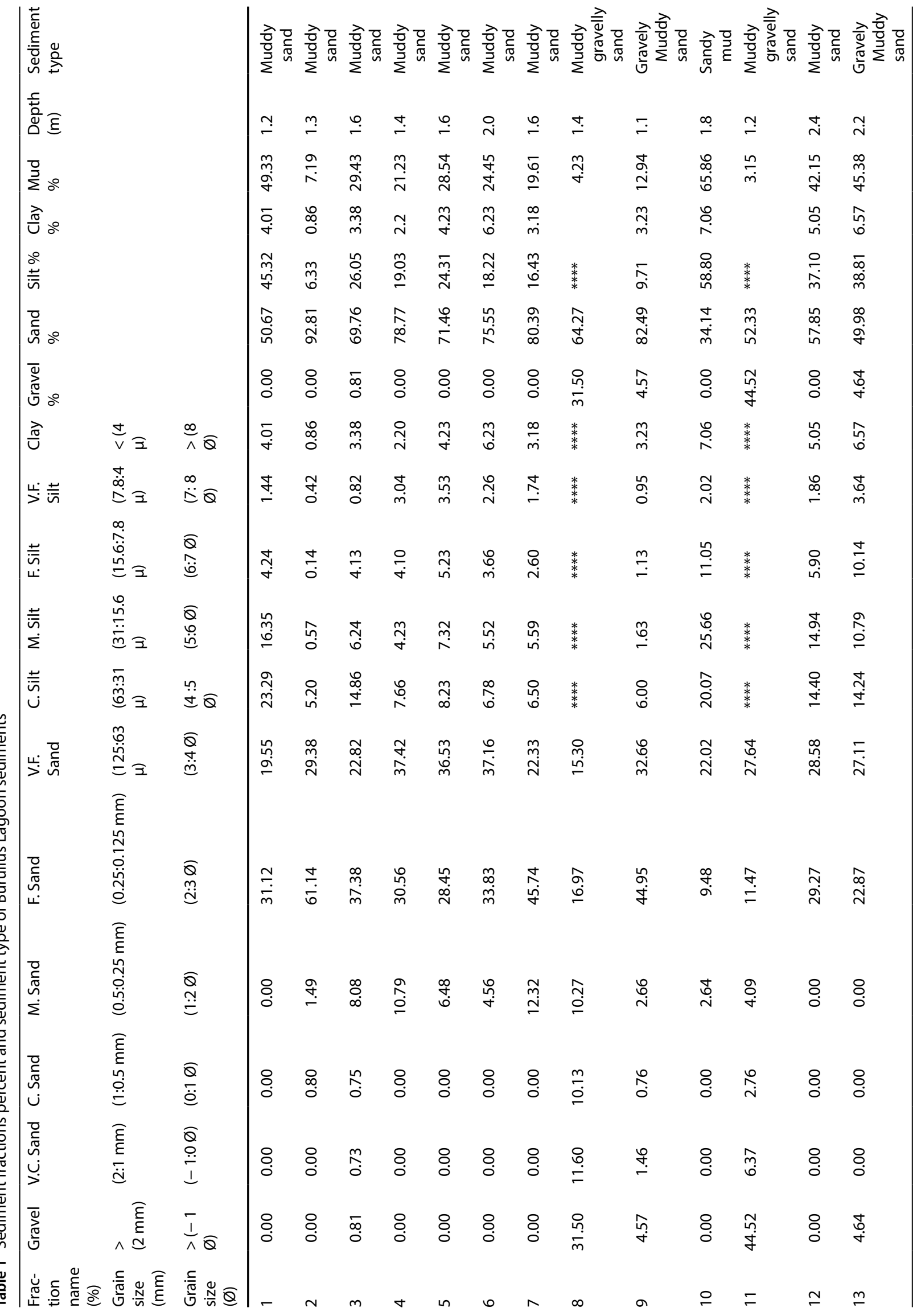




\begin{tabular}{|c|c|c|c|c|c|}
\hline 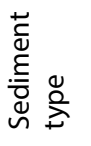 & & & & 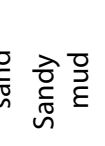 & \\
\hline 音 & & & $\stackrel{\sim}{\longrightarrow}$ & $\hat{i}$ & \\
\hline$\sum^{\frac{D}{2}} \delta^{\circ}$ & & & $\begin{array}{l}\stackrel{\infty}{\sim} \\
\stackrel{+}{\sim}\end{array}$ & $\underset{\infty}{\stackrel{i}{\sim}}$ & \\
\hline$\frac{\widehat{d}}{U} \circ \circ$ & & & $\stackrel{n ?}{r}$ & 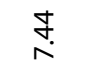 & \\
\hline $\begin{array}{l}\stackrel{\circ}{\circ} \\
\frac{ \pm}{n}\end{array}$ & & & $\underset{\sim}{\sim}$ & $\begin{array}{l}\hat{\imath} \\
\text { ò }\end{array}$ & \\
\hline 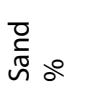 & & & 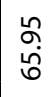 & 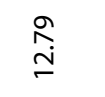 & \\
\hline$\underset{\substack{\tilde{D} \\
\frac{\pi}{\sigma}}}{\bar{\sigma}}$ & & & $\stackrel{\hat{N}}{\text { a }}$ & ¿ & \\
\hline$\frac{\widehat{\sigma}}{U}$ & $\stackrel{ \pm}{v} \Omega$ & $\stackrel{\infty}{\wedge} \bar{Q}$ & $\stackrel{n ?}{\underline{n}}$ & 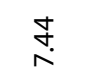 & \\
\hline$\stackrel{u}{>}$ & 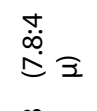 & $\stackrel{\infty}{\doteq} \widehat{Q}$ & 菖 & $\stackrel{\infty}{\stackrel{\leftrightarrow}{+}}$ & \\
\hline 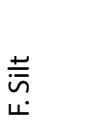 & 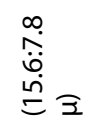 & $\begin{array}{l}\widehat{Q} \\
\hat{\dot{\theta}}\end{array}$ & $\frac{5}{6}$ & $\begin{array}{l}\stackrel{\circ}{\infty} \\
\stackrel{\infty}{+}\end{array}$ & \\
\hline $\begin{array}{l}\frac{ \pm}{\bar{n}} \\
\dot{\Sigma}\end{array}$ & $\begin{array}{l}\stackrel{0}{\dot{n}} \\
\stackrel{\ddot{m}}{\text { In }} \Omega\end{array}$ & $\begin{array}{l}\bar{Q} \\
\stackrel{0}{0} \\
\dot{\varphi}\end{array}$ & 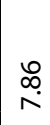 & $\underset{f}{\check{f}}$ & \\
\hline 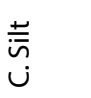 & $\begin{array}{l}\overline{\hat{m}} \\
\stackrel{\tilde{\theta}}{\Omega}\end{array}$ & $\stackrel{n}{\dot{I}} \widehat{Q}$ & 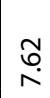 & $\begin{array}{l}\stackrel{\infty}{\infty} \\
\stackrel{\infty}{\infty}\end{array}$ & \\
\hline 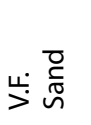 & 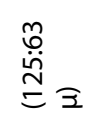 & $\begin{array}{l}\widehat{Q} \\
\dot{\mathscr{g}}\end{array}$ & $\frac{\circ}{\circ}$ & $\underset{\infty}{\stackrel{\infty}{\infty}}$ & \\
\hline 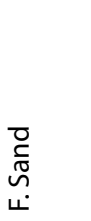 & 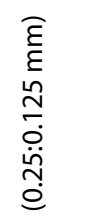 & $\begin{array}{l}\bar{Q} \\
\ddot{d}\end{array}$ & $\underset{m}{\stackrel{+}{m}}$ & $\underset{+}{\stackrel{+}{+}}$ & \\
\hline $\begin{array}{l}\text { D } \\
\text { ट } \\
\tilde{N} \\
\dot{\Sigma} \\
\dot{\Sigma}\end{array}$ & 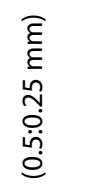 & $\begin{array}{l}\stackrel{Q}{Q} \\
\stackrel{ }{=}\end{array}$ & $\stackrel{\Xi}{\leftrightarrows}$ & 8 & 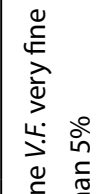 \\
\hline 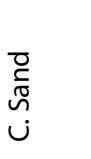 & $\begin{array}{l}\bar{\xi} \\
\varepsilon \\
n ٌ \\
\stackrel{\rho}{=}\end{array}$ & $\frac{\widehat{Q}}{\ddot{\theta}}$ & $\begin{array}{l}\stackrel{0}{\infty} \\
\stackrel{0}{\circ}\end{array}$ & $\stackrel{0}{\circ}$ & 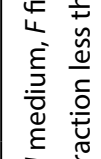 \\
\hline 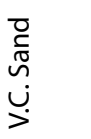 & $\begin{array}{l}\bar{\xi} \\
\bar{\varepsilon} \\
\ddot{d}\end{array}$ & 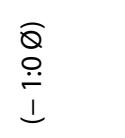 & 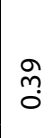 & 8 & 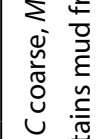 \\
\hline 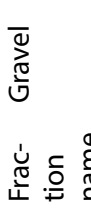 & 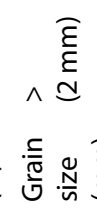 & 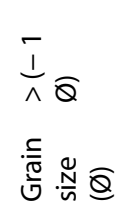 & సે & ষ্ণ & 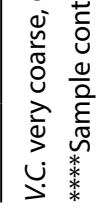 \\
\hline
\end{tabular}

SN Applied Sciences
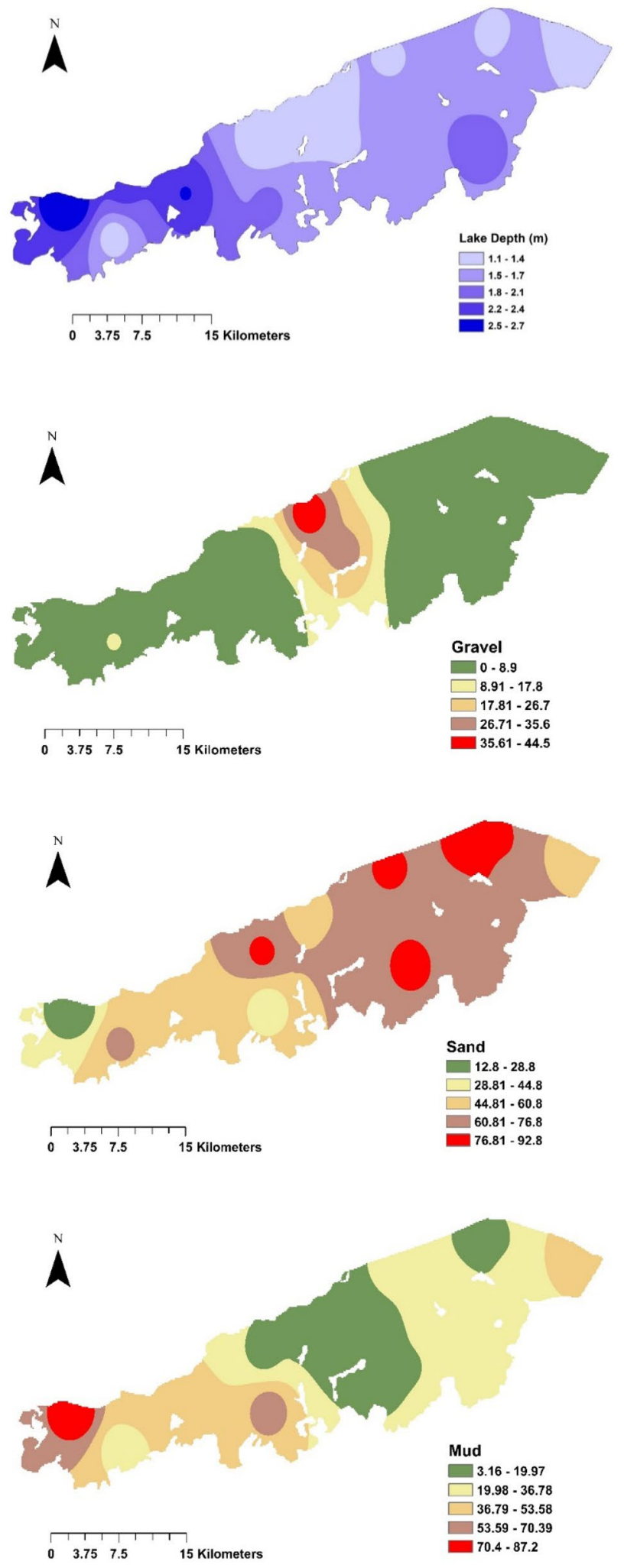

Fig. 2 Bathymetric map and spatial distribution of grain sizes (gravel, sand, and mud percent) in Burullus Lake 

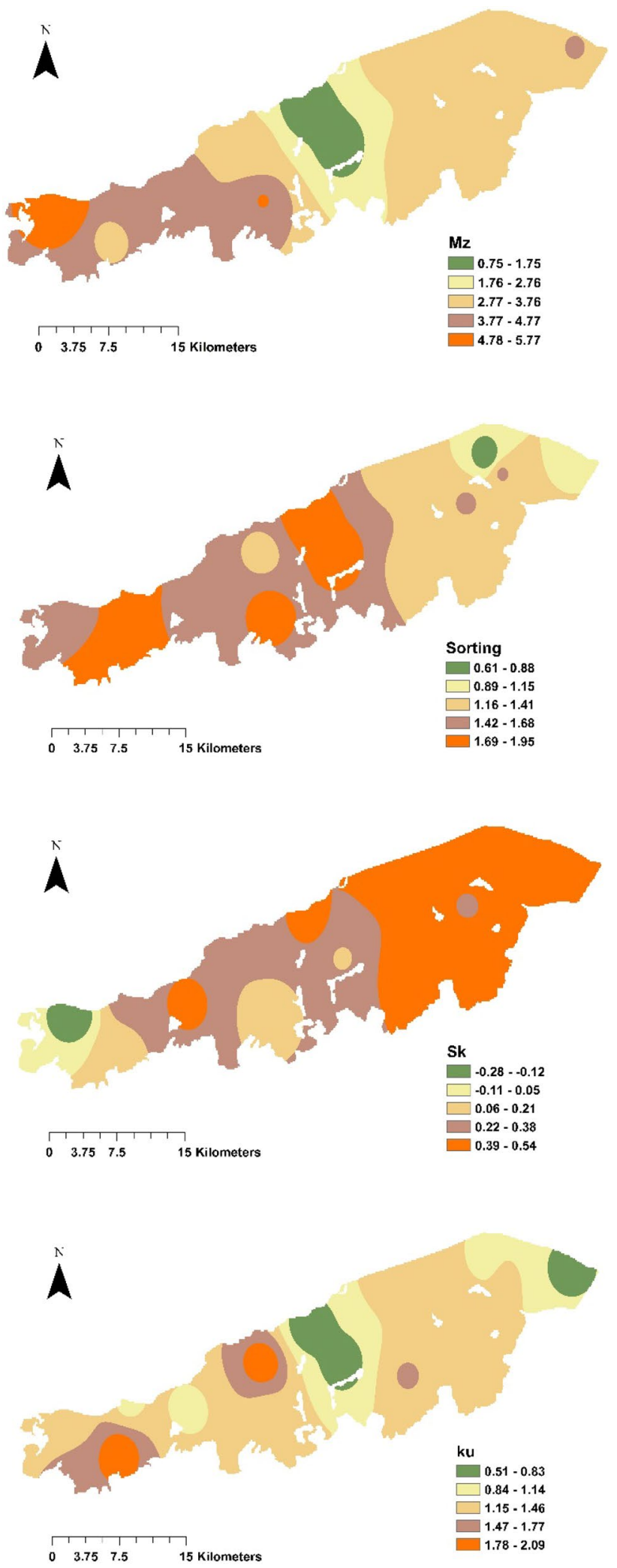

Fig. 3 The spatial distribution of textural parameters (mean size $(\mathrm{Mz})$, sorting, ske wness (Sk) and kurtosis (ku)) of Burullus Lake sediments

\section{Discussion}

Sediment characteristics (grain size and textural parameters) are considered as the topmost factor in controlling and regulating coastal lagoons systems. Also, it is significant to its structure and effective in management and conservation. The data obtained are broadly consistent with the major trends which state in a coastal lagoon, the wide distribution of coarse fractions in/near sea connections signifies high-energy transporting environments, whereas fine fractions characterize quieter depositional environments within the lagoon [8].

Like the other Southern Mediterranean coastal lagoons, Nile (riverine) deposits supplies are stopped as a result of Aswan High dam building with consequent appeared erosion problems on the seaward margin of the lagoon. Moreover, the fresh but often contaminated Nile water inflow into Egyptian coastal lagoons is now completely regulated by Irrigation Ministery $[1,53,56]$.

In agreement with Flower et al. [12], aquatic vegetation within Burullus lagoon controls transportation and deposition of sediment. Increasing of coarse fractions northward may be due to wave actions and lacking sources of fine suspended matter (away from drains effluent), in addition to high productivity (which partly explains the high accumulation of carbonate shells, i.e. high gravel fraction sites). Areas in which drains discharge their effluents, fine fractions trapped and deposited directly after entering of the lagoon. The relative affluence of mud fractions (silt and clay) are well-ordered by hydraulic sorting. Moreover, as silt fraction (as relatively coarse fractions) are more likely to be amassed in shallow destinations than the smaller clay particles, which reaccumulated in more profound destinations of the tidal pond. In addition, our results concurred with [3, 35] who revealed that the lagoonal sediments are muddy and considered as organic-rich sediments with thin and wave-rippled sands.

Present results of mean grain size indicate that it was controlled by sediments sources. Studied sites receive sediments from biogenic (alloctnous) and terrigenous (autoctonous) sources with different transporting agents. The spatial variation of mean grain size (coarse sand to medium silt) may verify different sediments sources, different erosion and accretion regions, as well as, the impact of shell fragments. Sediments sorting indicates fluctuations in kinetic energy or changes in depositing agent velocity [51]. Fine sediments are better sorted than coarser to medium sediments. Sorting of Burullus sediments was poorly sorted, which indicate turbulent conditions $[19,20,38,62]$. Skewness measures the asymmetry of a frequency distribution. Positive 
Table 2 Textural parameters of Burullus Lake sediments

\begin{tabular}{lllll}
\hline Site & Mean size $(\mathrm{Mz})$ & Sorting $\left(\sigma_{\mathrm{l}}\right)$ & Skewness $\left(\mathrm{SK}_{\mathrm{l}}\right)$ & Kurtosis $\left(\mathrm{K}_{\mathrm{G}}\right)$ \\
\hline 1 & Very fine sand & Poorly sorted & Strongly fine-skewed & Platy-kurtic \\
2 & Fine sand & Medium well sorted & Strongly fine-skewed & Meso-kurtic \\
3 & Very fine sand & Poorly sorted & Strongly fine-skewed & Lepto-kurtic \\
4 & Very fine sand & Poorly sorted & Strongly fine-skewed & Lepto-kurtic \\
5 & Very fine sand & Poorly sorted & Strongly fine-skewed & Lepto-kurtic \\
6 & Very fine sand & Poorly sorted & Strongly fine-skewed & Lepto-kurtic \\
7 & Very fine sand & Poorly sorted & Strongly fine-skewed & Very lepto-kurtic \\
8 & Coarse sand & Poorly sorted & Fine-skewed & Very platy-kurtic \\
9 & Very fine sand & Poorly sorted & Fine-skewed & Very lepto-kurtic \\
10 & Coarse silt & Poorly sorted & Near symmetrical & Lepto-kurtic \\
11 & Coarse sand & Poorly sorted & Strongly fine-skewed & Very platy-kurtic \\
12 & Coarse silt & Poorly sorted & Strongly fine-skewed & Meso-kurtic \\
13 & Coarse silt & Poorly sorted & Strongly fine-skewed & Meso-kurtic \\
14 & Very fine sand & Poorly sorted & Fine-skewed & Very lepto-kurtic \\
15 & Medium silt & Poorly sorted & Coarse-skewed & Lepto-kurtic \\
\hline
\end{tabular}

Fig. 4 CM diagram for Burullus Lake sediment (a: according to Passega [40] and Passega \& Byramjee [41]; b: according to Ludwikowska-Kędzia [24])

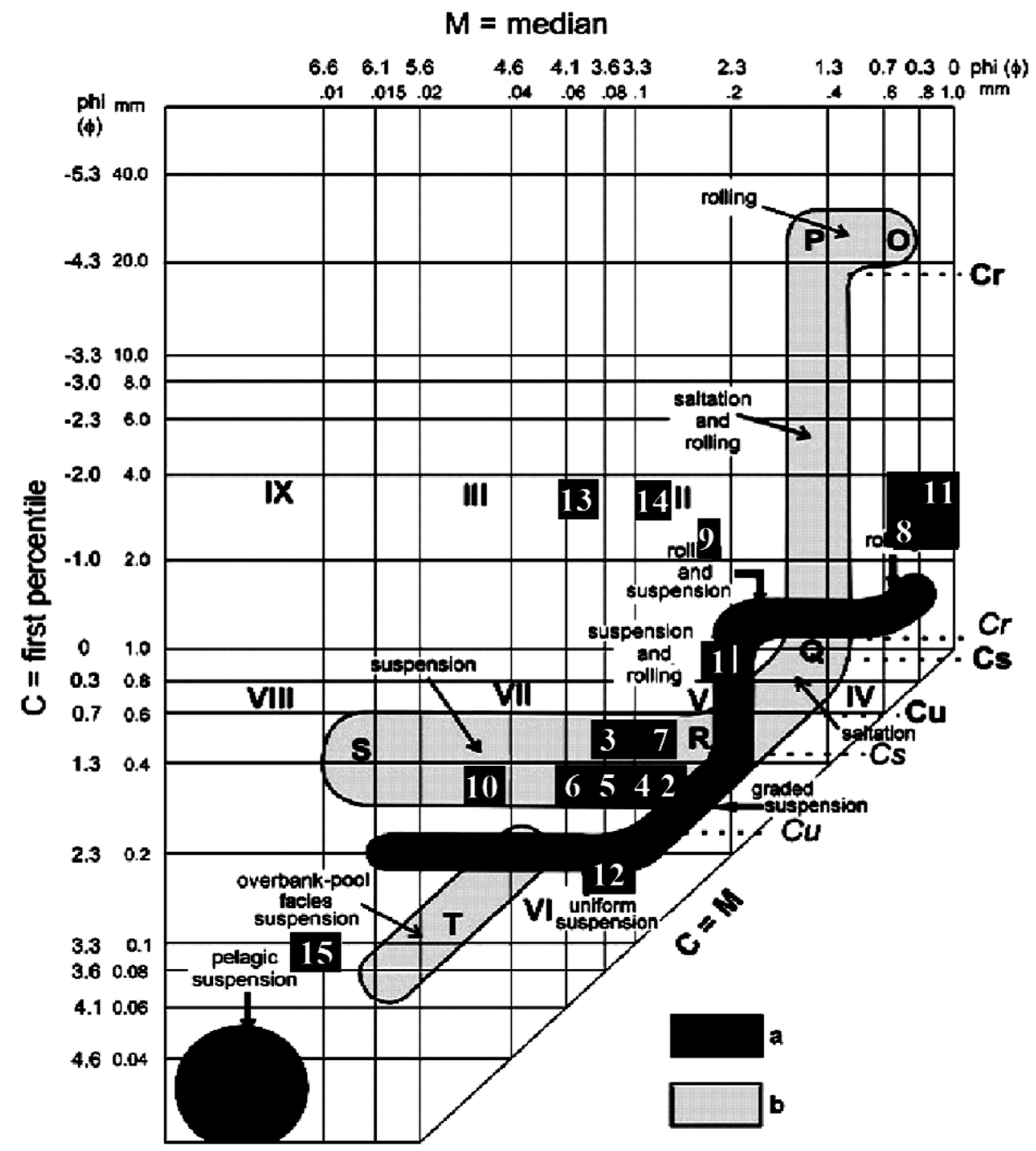


Table 3 Mode of Transportation and paleoenvironmental used applications results of Burullus Lake sediments

\begin{tabular}{|c|c|c|c|c|c|c|c|c|c|c|}
\hline \multirow[t]{3}{*}{ Site } & \multirow{2}{*}{\multicolumn{2}{|c|}{ C-M Mode of Transportation }} & \multicolumn{5}{|c|}{$\begin{array}{l}\text { Truncation lines at inflection points of } \\
\text { the cumulative curves }\end{array}$} & \multirow{2}{*}{\multicolumn{3}{|c|}{$\begin{array}{l}\text { Discriminant Func- } \\
\text { tions }\end{array}$}} \\
\hline & & & \multicolumn{2}{|c|}{$\begin{array}{l}\text { Traction/ } \\
\text { Saltation }\end{array}$} & \multicolumn{2}{|c|}{$\begin{array}{l}\text { Saltation/ } \\
\text { Suspension }\end{array}$} & \multirow{2}{*}{$\begin{array}{l}\text { Suspension } \\
\text { Wt\% }\end{array}$} & & & \\
\hline & Code & Mode & $\varnothing$ & Wt\% & $\varnothing$ & $\mathrm{Wt} \%$ & & $V_{1}$ & $V_{2}$ & Envi. \\
\hline 1 & $(\mathrm{P}-\mathrm{Q})$ & Suspension and rolling & 3.00 & 31.00 & 8.00 & 65.00 & 4.00 & 3.08 & 1.06 & Turbidi \\
\hline 2 & $(\mathrm{~S}-\mathrm{R})$ & Homogeneous suspension & 5.00 & 98.00 & 8.00 & 1.20 & 0.80 & 2.33 & 1.54 & River \\
\hline 3 & $(S-R)$ & Homogeneous suspension & 1.00 & 2.50 & 8.00 & 96.50 & 1.00 & 3.68 & 0.92 & Turbidit \\
\hline 4 & $(S-R)$ & Homogeneous suspension & 4.00 & 84.00 & 8.00 & 14.00 & 2.00 & 3.32 & 1.09 & Turbidite \\
\hline 5 & $(\mathrm{~S}-\mathrm{R})$ & Homogeneous suspension & 4.00 & 72.00 & 8.00 & 23.50 & 4.50 & 3.52 & 0.93 & Turbidite \\
\hline 6 & $(S-R)$ & Homogeneous suspension & 4.00 & 75.50 & 8.00 & 18.50 & 6.00 & 3.39 & 1.26 & Turbidite \\
\hline 7 & $(\mathrm{~S}-\mathrm{R})$ & Homogeneous suspension & 4.00 & 81.00 & 8.00 & 15.00 & 4.00 & 3.46 & 1.35 & Turbidite \\
\hline 8 & (l) & Rolling & 2.00 & 64.00 & 4.00 & 32.00 & 4.00 & 2.88 & -0.82 & Turbidite \\
\hline 9 & (II) & Rolling & 2.00 & 9.50 & 8.00 & 87.50 & 3.00 & 3.45 & 1.82 & Turbidite \\
\hline 10 & $(S-R)$ & Homogeneous suspension & 4.00 & 34.00 & 8.00 & 59.00 & 7.00 & 4.89 & 0.86 & Turbidite \\
\hline 11 & (l) & Rolling & 2.00 & 58.00 & 4.00 & 39.00 & 3.00 & 3.14 & -1.06 & Turbidite \\
\hline 12 & $(\mathrm{~S}-\mathrm{R})$ & Homogeneous suspension & 3.00 & 29.00 & 8.00 & 66.00 & 5.00 & 4.07 & 0.87 & Turbidite \\
\hline 13 & (II) & Rolling & 2.00 & 4.50 & 8.00 & 89.50 & 6.00 & 4.90 & 0.30 & Turbidite \\
\hline 14 & (II) & Rolling & 2.00 & 11.50 & 8.00 & 87.00 & 1.50 & 4.92 & 0.97 & Turbidite \\
\hline 15 & $(\mathrm{~T})$ & Pelagic suspension & 7.00 & 43.00 & 9.00 & 49.50 & 7.50 & 4.73 & 1.45 & Turbidite \\
\hline
\end{tabular}

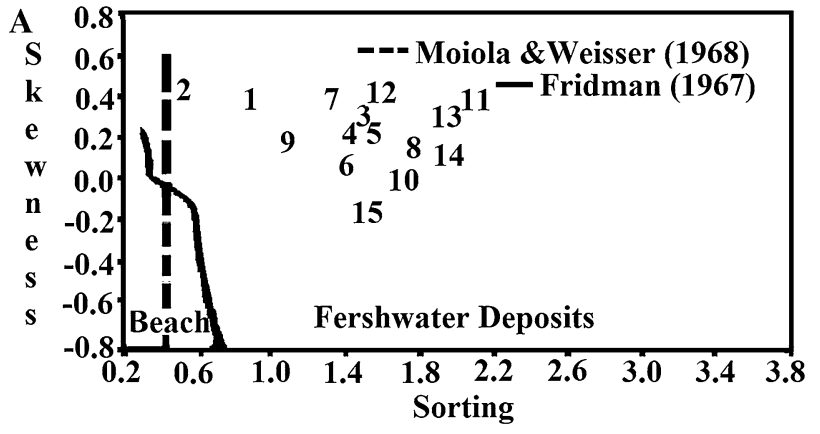

B

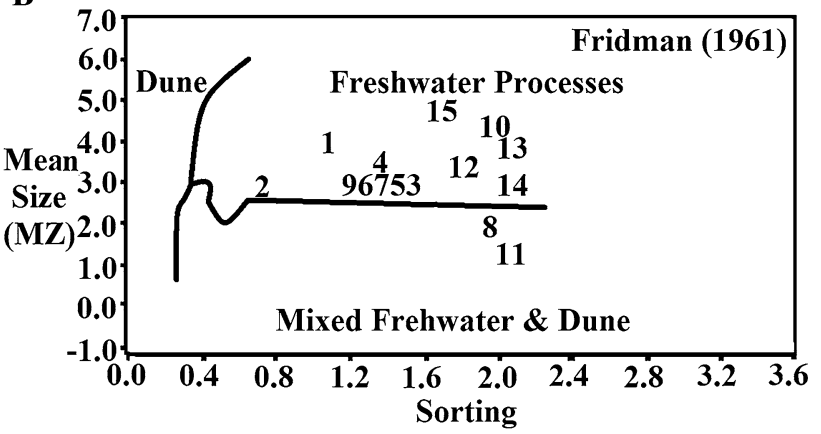

Fig. 5 Bivariate plots of Burullus Lake sediments

skewness exemplifies the area of deposition, whereas the sediments are negatively skewed where high-energy environment prevailing [6]. Consequently, positive skewness of Burullus sediments indicates that it is classified as environments undergoing depositional trends. Kurtosis values indicate the medium of deposition flow characteristics $[2,47]$. With no particular trend, the majority of eastern sites were lepto-kurtic in its nature, these indicates that the sediment is a mixture of a main population of medium sand in addition to a subordinate populations of other grain sizes [13]. Other sites were platy-kurtic. Platy-kurtic nature of sediments with variation in sorting values reveal both maturities of the sediments particles and continuous addition of finer/coarser particles with variable proportions [46].

Sedimentation occurs when the energy of the transporting medium decreases to the lowest level to continue the transport process. Then, sediments accumulated in horizontal layers, one top to the other. As result of this process, certain characteristic depositional features develop within the sediment layers, indicating clear information about the mode of deposition, and therefore evidences of its environment of deposition $[25,34,38,57]$.

Grain size has the basic role in classifying sedimentary facies, mode of transportation and deposition environments. Several studies indicate many criteria and applications to distinguish the grain size distributions and its mode of transportation. Cumulative curves consist of a number of different line segments, each one clears categories of particles (populations), which was transported in different modes of transportation $[22,33,38,55,58]$. CM diagram is used to identifying sediments mode of transportation by processing the results of grain-size for determining the environment dynamics of their transport and. CM diagram differentiates between traction 
Fig. 6 Multigroup multivariant discriminant functions $V_{1}-V_{2}$ plot for Burullus Lake

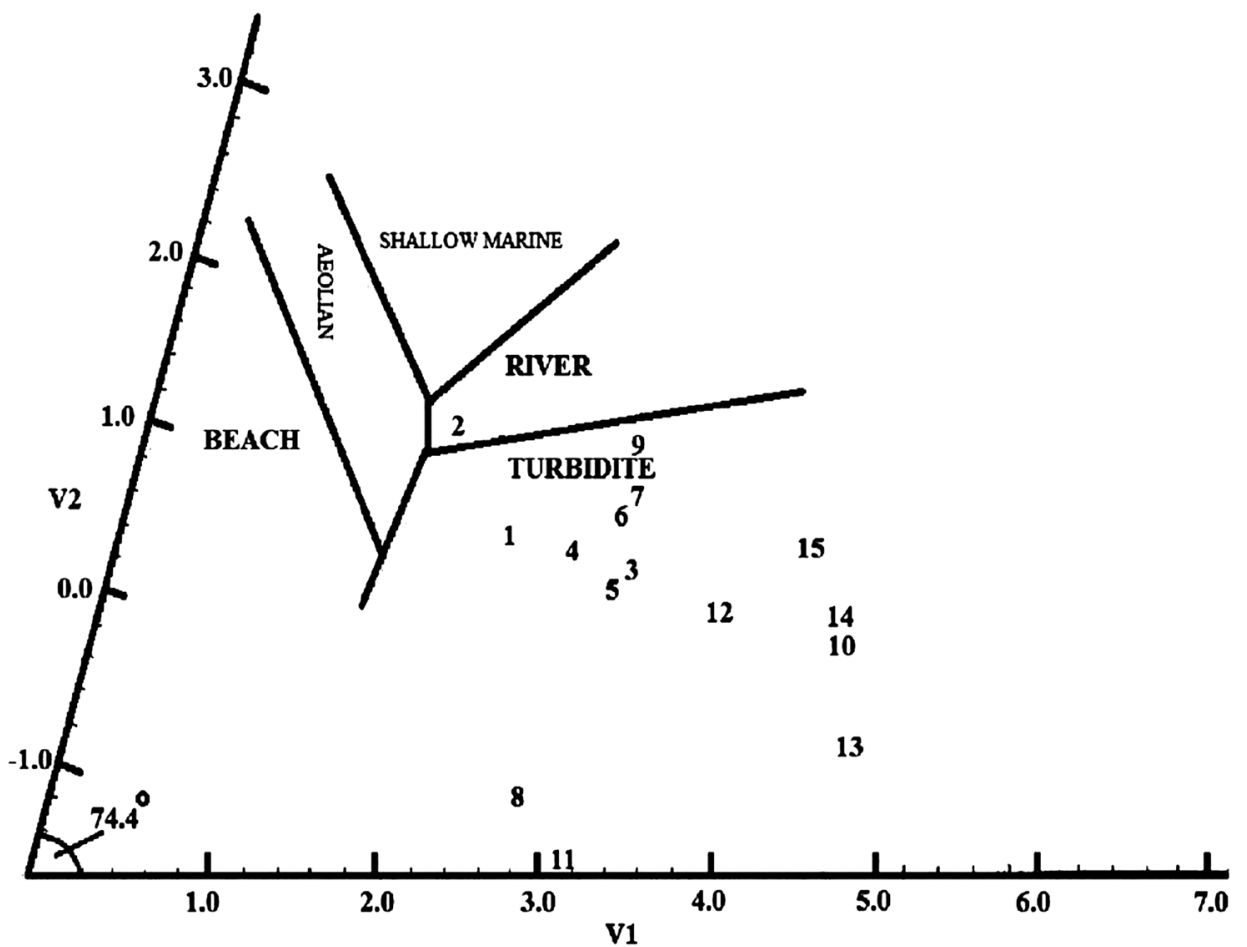

(rolling), saltation (homogenous suspension) and suspension with rolling [24, 33, 38-41].

CM application is widely used by many authors to interpret different depositional environments $[9,22,34$, $38,44,55]$. CM patterns of the studied sites mostly indicate homogenous suspension ( $\mathrm{S}-\mathrm{R}$ segment) especially at regions of drains discharge, where drains effluents enter the lagoon carrying suspended particles, which begin to deposit directly after entering of the lagoon (due to a sudden decrease in current velocity). Furthermore, at anywhere else; due to re-disposition of fine sediments particles in relatively deeper areas homogenous suspension occurred. CM indicates rolling pattern (I and II sectors) at sites where coarse fractions percent increase (indicating the impact of shell and shell fragments northward).

With clear different sectors, straight line and inflection points of created cumulative curves of studied lagoon sediments indicate that siltation is the main transportation mode, followed by suspension whereas truncation was of less importance. These results support the CM diagram results. Additionally, it implies that sediments are classified as the third type of cumulative curves, which could be a transitional group involving blended sediments shaped by short-lived depositional forms (i.e. dregs coming about from a number of covering forms and depositional situations) $[22,33,38,58]$.

Sediments textures indicate the sedimentary processes (weathering, erosion, and mode of transport).
It acts as the basis for classifying sedimentary environments as well as the source material of sediments [16-18, 30, 38, 51, 57].

Bivariate plots of several granulometric parameters (i.e. $M_{z}$ vs. $\sigma_{1}$ and $\sigma_{1}$ vs. $S k_{1}$ ) are used for understanding and interpretation of depositional history and mode of transportation of ancient as well as modern sedimentary deposits [17, 18, 24, 30, 33]. The combination between bivariate diagram results indicates strong freshwater processes signatures in the deposition of sediments. These results may be due to that the investigated lagoon is a part of River Nile delta, in addition to the lake is located at termini of a great irrigation system.

Moreover, determination of depositional environment of coastal lagoon has been carried out using the multigroup multivariate discriminant algorisms suggested by Sahu [52]. Results reveal that Burullus Lagoon sediments fall in the field of turbidite deposition. These results support results obtained by both of CM diagram application and straight line and inflection points of created cumulative curves. These results are in good agreement with other studies which have shown that homogenous suspension suggests higher turbulence, which proposes definite characteristics of grain-size distribution in sediments transported by running water and turbidity currents [24, 33, 38-41]. 


\section{Conclusion}

Based on the results it can be concluded that, in Burullus Lagoon, the wide distribution of coarse fractions in/ near inlet signify high-energy transporting environments, whereas fine fractions characterize quieter depositional sites within the lagoon. The mean grain size was controlled by sediments sources. Poorly sorted sediments indicate fluctuations in kinetic energy or changes in depositing agent velocity. Deposition environment of Burullus coastal lagoon sediments is turbidite dominant with strong freshwater processes signatures. The saltation was the main mode of transportation, followed by suspension while truncation was of less importance. Burullus Lagoon sediments are classified as sediments resulting from a number of overlapping processes and depositional environments, which proposes definite characteristics of grain-size distribution in sediments transported by running water and turbidity in addition to the rolling pattern at sites where coarse fraction percentage increase existed.

Data availability statement The corresponding author was responsible for the dissemination of the supportive data of the present study on request.

\section{Compliance with ethical standards}

Conflict of interest On behalf of author, the corresponding author states that there is no conflict of interest.

\section{References}

1. Ahmed MH, El Leithy BM, Thompson JR, Flower RJ, Ramdani M, Ayache F, Hassan SM (2009) Application of remote sensing to site characterisation and environmental change analysis of North African coastal lagoons. Hydrobiologia. https://doi. org/10.1007/s10750-008-9682-8

2. Baruah J, Kotoky P, Sarma JN (1997) Textural and geochemical study on river sediments: a case study on the Jhanji River, Assam. J Indian Assoc Sedimentol 16(1):195-206

3. Boggs S Jr (2006) Principles of sedimentology and stratigraphy. Prentice Hall, New York

4. Bollina S, Conde D, Aubriot L, Perez MC (2005) Influence of hydrology on phytoplankton species composition and life strategies in a subtropical coastal lagoon periodically connected with the Atlantic Ocean. Estuaries 28:884-895

5. Carver RE (1971) Procedures in sedimentary petrology. Wiley, New York

6. Duane DB (1964) Significance of skewness in recent sediments, Western Pamlico Sound, North California. J Sediment Petrol 34(4):864-874

7. El-Adawy A, Negm A, Elzeir M, Saavedra O, El-Shinnawy I, Nadaoka K (2013) Modeling the hydrodynamics and salinity of El-Burullus Lake (Nile Delta, Northern Egypt). J Clean Energy Technol 1(2):157-163
8. El-Said GF, Draz SE, El-Sadaawy MM, Moneer AA (2014) Sedimentology, geochemistry, pollution status and ecological risk assessment of some heavy metals in surficial sediments of an Egyptian lagoon connecting to the Mediterranean Sea. J Environ Sci Health Part A Toxic/Hazard Subst Environ Eng 49(9):1029-1044

9. Farhat IH, Salem GS (2015) Effect of flooding on distribution and mode of transportation of Lake Nasser sediments, Egypt. Egypt J Aquat Res 41:165-176

10. Fayed DB (2004) Aspects of Manzalah Lake Pollution on Mugil Species. M.Sc. Thesis, Girls' College, Ain Shams University

11. Flemming BW (2007) The influence of grain-size analysis methods and sediment mixing on curve shapes and textural parameters: implications for sediment trend analysis. Sed Geol 202:425-435

12. Flower RJ, Appleby PG, Thompson JR, Ahmed MH, Ramdani M, Chouba L, Rose N, Rochester R, Ayache F, Kraiem MM, Elkhiati N, El Kafrawy S, Yang H, Rasmussen EK (2009) Sediment distribution and accumulation in lagoons of the Southern Mediterranean Region (the MELMARINA Project) with special reference to environmental change and aquatic ecosystems. Hydrobiologia 2009(622):85-112. https://doi.org/10.1007/s10750-008-9674-8

13. Folk RL (1966) A review of grain-size parameters. Sedimentology 6:73-93

14. Folk RL (1974) Petrology of sedimentary rocks. Himplill Publ. Co., Austin, Texas, $182 \mathrm{p}$

15. Folk RL (2014) Petrology of sedimentary rocks. Hemphills Publ, Austin, p 170

16. Folk RL, Ward W (1957) Brazos River bar, a study in the significance of grain size parameters. J Sediment Petrol 27:3-26

17. Friedman GM (1961) Distinction between (sic) dune, beach and river sands from their textural characteristics. J Sediment Petrol 31:514-529

18. Friedman GM (1967) Dynamic processes and statistical parameters compares for size frequency distribution of beach and river sands. J Sediment Petrol 37:327-354

19. Griffith JC (1951) Size versus sorting in Caribbean sediments. J Geol 59(3):211-243

20. Inman DL, Chamberlain FK (1955) Particle size distribution in nearshore sediments. In: Hough JL, Mearad HW (eds) Finding Ancient Shorelines. Soc. Econ. Paleont. Miner. Spec. Publ. 3:106129. J Geol 56(6, Nov. 1948):526-577

21. Kalińska-Nartiša E, Stivrins N, leva Grudzinska I (2018) Quartz grains reveal sedimentary palaeoenvironment and past storm events: a case study from eastern Baltic. Estuar Coast Shelf Sci 200:359-370

22. Kalińska-Nartiša $E$, Alexanderson $H$, Nartišs M, Stevic M, Kaiser K (2017) Sedimentary features reveal transport paths for Holocene sediments on the Kristianstad coastal plain, SE Sweden. GFF 139(2):147-161. https://doi.org/10.1080/11035897.2017.12906 75

23. Kalińska-Nartiša $E$, Nartišs M (2016) Sandy fan-like forms in the central-eastern Mazovian Lowland (Central Poland): textural record and chronology. Geog Ann Ser A Phys Geogr 98:111-127

24. Ludwikowska-Kędzia $M$ (2000) Evolution of the middle segment of the Belnianka River valley in the Late Glacial and Holocene. Dialog Press, Warsaw

25. Maity KS, Maiti R (2016) analysis of sedimentation in connection to grain size and shear strees at lower reach of the Rupnarayan River, West Bengal, India. Indian J Geo-Mar Sci 45(9):1128-1137

26. Marcinkowski B, Mycielska-Dowgiao E (2013) Heavy-mineral analysis in Polish investigations of Quaternary deposits: a review. Geologos 19(1-2):5-23

27. McCave LN (1978) Grain size trends and transport along beaches: example from eastern England. Mar Geol 28(1-2):M43-M51

28. McLaren $P$ (1981) An interpretation of trends in grain size measures. J Sediment Petrol 51(2):611-624 
29. McLaren P, Bowles D (1985) The effects of sediment transport on grain size distributions. J Sediment Petrol 55(4):457-470

30. Moiola RJ, Weiser D (1968) Textural parameters: an evolution. J Sediment Petrol 38:45-53

31. Morton A, Hounslow MW, Frei D (2013) Heavy-mineral, mineralchemical and zircon-age constraints on the provenance of Triassic sandstones from the Devoncoast, southern Britain. Geologos 19(1):67-85

32. Mycielska-Dowgiao E, Woronko B (2004) The degree of aeolization of Quaternary deposits in Poland as a tool for stratigraphic interpretation. Sediment Geol 168:149-163

33. Mycielska-Dowgiałło E, Ludwikowska-Kędzia M (2011) Alternative interpretation of grain-size data from Quaternary deposits. Geologos 17(4):189-203. https://doi.org/10.2478/v1011 8-011-0010-9

34. Natesan U, Deepthi K, Muthulakshmi AL, Ferrer A, Narasimhan SV, Venugopalan VP (2012) Textural and depositional processes of surface sediments of Kalpakkam, Southeast Coast of India. Front Earth Sci 6(4):392-404. https://doi.org/10.1007/s1170 7-012-0330-2

35. Nichols G (2009) Sedimentology and stratigraphy. Wiley, New York

36. Nordstrom KF (1989) Downdrift coarsening of beach foreshore sediments at tidal inlets: an example from the coast of New Jersey. Earth Surf Process Landf 14(8):691-701

37. Okbah MA, Hussein NR (2006) Impact of environmental conditions on the phytoplankton structure in Mediterranean Sea lagoon Lake Burullus. Egypt Water Air Soil Pollut 172:129-150

38. Parthasarathy P, Ramesh G, Ramasamy S, Arumugam T, Govindaraj P, Narayanan S, Jeyabal G (2016) Sediment dynamics and depositional environment of Coleroon river sediments, Tamil Nadu, Southeast coast of India. J Coast Sci 3(2):1-7

39. Passega $R$ (1957) Texture as a characteristic of clastic deposition. Bull Am Assoc Pet Geol 41:1952-1984

40. Passega R (1964) Grain-si ze representation by CM patterns as a geological tool. J Sediment Petrol 34:830-847

41. Passega R, Byramjee R (1969) Grain-size image of clastic deposits. Sedimentology 13:233-252

42. Pettijohn FJ (1975) Sedimentary rocks, 3rd edn. Harper \& Row, New York, p 628

43. Pettijohn FJ, Ridge JD (1932) A textural variation series of beach sands from Cedar Point, Ohio. J Sediment Res 2(2):76-88

44. Pisarska-Jamroży M (2013) Varves and megavarves in the Eberswalde Valley (NE Germany) - a key for the interpretation of glaciolimnic processes. Sed Geol 291(2013):84-96

45. Plumley WJ (1948) Black Hills Terrace Gravels: a study in sediment transport. J Geol 56(6):526-577

46. Rao PA, Anilkumar V, Yugandhar Rao A, Ravi GS, Krishnan S (2001) Grain size parameters in the interpretation of depositional environments of coastal sediments between Bendi creek and Vamsadhara River, East Coast, India. J Indian Assoc Sedimentol 20(1):106-116

47. Ray AK, Tripathy SC, Patra S, Sarma VV (2006) Assessment of Godavari estuarine mangrove ecosystem through trace metal studies. Environ Int 32:219-223
48. Reading HG, Collinson JD (1996) Clastic Coasts. In: Reading HG (ed) Sedimentary environments: process: facies and stratigraphy. Blackwells, Cornwall, pp 154-231

49. Russell JS, Judd $P$ (1959) After-effects of the 1956-1957 flood on the lower Murray swamps. Agric (S. Afr.) 62:104-123

50. Rust BR (1984) Sedimentation in fluvial and lacustrine environments. Hydrobiologia 91:59-70

51. Sahu BK (1964) Depositional Mechanism from the size analysis of clastie sediments. J Sediment Petrol 34(1):78-83

52. Sahu BK (1983) Multigroup discrimination of depositional environments using size distribution statistics. Indian J Earth Sci 10(1):20-29

53. Shahin M (1985) Hydrology of the Nile Basin. Elsevier, Amsterdam

54. Shaltout $\mathrm{KH}, \mathrm{Al}-\mathrm{Sodany} \mathrm{YM}$ (2008) Vegetation analysis of Burullus Wetland: a RAMSAR site in Egypt. Wetl Ecol Manag 16:421-439

55. Srivastava AK, Ingle PS, Lunge HS, Khare N (2012) Grain-size characteristics of deposits derived from different glacigenic environments of the Schirmacher Oasis, East Antarctica. Geologos 18(4):251-266

56. Thompson JR, Flower RJ, Ramdani M, Ayache F, Ahmed MH, Rasmussen EK, Petersen OS (2009) Hydrological characteristics of three North African coastal lagoons: insights from the MELMARINA project. Hydrobiologia. https://doi.org/10.1007/s1075 0-008-9680-x

57. Venkatesan S, Singarasubramanian SR (2015) Depositional Environmental studies of sediments near Arasalar river mouth, Karaikal region Pondicherry Union Territory, East coast of India. Int Res J Eng Technol 2(2):677-678

58. Visher GS (1969) Grain size distribution and deposi-tional processes. J Sediment Petrol 39:1074-1106

59. Wachecka-Kotkowska L, Ludwikowska-Kędzia M (2013) Heavymineral assemblages from fluvial Pleniglacial deposits of the Piotrkow Plateau and the Holy Cross Mountains-a comparative study. Geologos 19:131-146

60. Wai OWH, Wang CH, Li YS, Li XD (2004) The formation mechanisms of turbidity maximum in the Pearl River estuary, China. Mar Pollut Bull 48:441-448

61. Woronko B, Rychel J, Karasiewicz MT, Ber A, Krzywicki T, Marks L, Pochocka-Szwarc K (2013) Heavy and light minerals as a tool for reconstruction of depositional environments: an example from the Jaowka site (northern Podlasie region, NE Poland). Geologos 19(1):47-66

62. Zhang W, Jin H, Yao X, Ji Z, Zhang X, Yu X, Zhang F, Gao A (2015) Grain size composition and transport of sedimentary organic carbon in the Changjiang River (Yangtze River) Estuary and Hangzhou Bay and their adjacent waters. Acta Oceanol Sin 34(10):46-56

Publisher's Note Springer Nature remains neutral with regard to jurisdictional claims in published maps and institutional affiliations. 